\title{
Impact of Different Dates of Sowing and Irrigation Levels on Chickpea Nodulation
}

\author{
Sonam Sah ${ }^{1}$, R.N. Singh ${ }^{2}$ and A.S. Nain ${ }^{1}$ * \\ ${ }^{1}$ G. B. Pant University of Agriculture \& Technology, Pantnagar-263 145,U. S. Nagar, \\ Uttarakhand, India \\ ${ }^{2}$ ICAR-National Institute of Abiotic Stress Management, Baramati,-413 115, Pune, \\ Maharashtra, India \\ *Corresponding author
}

\section{A B S T R A C T}

Keywords

Chickpea,

Nodulation,

Relative growth rate, Irrigation level

Article Info

Accepted:

07 October 2019

Available Online:

10 November 2019
An experiment was conducted to assess the impact of dates of sowing and irrigation levels on nodulation of chickpea (Pusa-362) during 2017-18 at GBPUA\&T, Uttarakhand. Three different dates of sowing and two irrigation levels were applied. The results revealed that the sowing on $29^{\text {th }}$ November produced highest number and dry weight of nodules followed by $10^{\text {th }}$ and $24^{\text {th }}$ December. Applying irrigation twice to the crop resulted into higher number and mass of root nodules as compared to single irrigation. Relative growth rate of number and dry weight of root nodules per plant was found to be positively correlated with prevailing relative humidity while it was negatively correlated with mean temperature. Our findings on nodulation dynamics indicate inverse relation between daily temperature and chickpea root nodulation. The root nodulation is also sensitive to soil moisture and relative humidity and found to be positively correlated with these two parameters. The information from this study can be used as an important input to suggest dates of sowing and water management in chickpea.

\section{Introduction}

Chickpea is one of the most important pulses crops of world. India being the largest producer contributes $75 \%$ of world chickpea production. In India, it covers maximum area among all the pulses crops grown in the country and is grown over 10.56 million hectare of area. Its production steadily rose over the years and at present, registers about 11.23 million tones with productivity accounting about $1063 \quad \mathrm{~kg} / \mathrm{ha}$ 
(DAC\&FW,2018).Chickpea is a small, branched, herbaceous plant of family Leguminosae and possess palmate shaped root nodules. Being a leguminous plant, it promotes soil health by fixing atmospheric nitrogen symbiotically through the phenomena of symbiosis in association with Rhizobium $s p$ thereby improving soil fertility. The proportion of nitrogen requirement met through symbiotic nitrogen fixation has been found to be highly variable under irrigated and dryland conditions. Multiple biotic and abiotic factors affecting nodulation account for this variability. Apart from genetic background of both symbiotic partners, environmental factors such as soil water content, aeration, temperature govern the extent of nodulation. Soil moisture plays a crucial role in establishment of nodules of legumes with magnitude of impact depending upon the severity of stress (Serraj and Sinclair, 1998). Root hair infection by bacteria and early phase of nodulation are very sensitive to temperature. Deviation from optimum temperature exhibits impedance against nodulation thus, delaying the process (Lira et al., 2005). Also, at later stages too high temperature speeds up the process of senescence causing premature decaying of root nodules. (Bordeleau and Prévost, 1994). Keeping this in view an experiment was laid in GBPUA\&T, Uttarakhand in rabi 2017-18 to assess the impact of different dates of sowing and irrigation levels on chickpea nodulation.

\section{Materials and Methods}

\section{Details of the experimental site}

The experiment was laid out in the field C5 of Norman E. Borlaug Crop Research Centre of Govind Ballabh Pant University of Agriculture and Technology, Pantnagar, U.S. Nagar (Uttarakhand). The topography of the experimental site is fairly uniform. Pantnagar lies in the Tarai belt at the foothills of the Western Himalayas at $29.03^{\circ} \mathrm{N}$ latitude, $79.48^{\circ} \mathrm{E}$ longitude and at an altitude of $231 \mathrm{~m}$ above the mean sea level.

\section{Climate}

The experimental site is characterized as humid subtropical, with high temperatures during summers (March to June). Generally there is intense rainfall during monsoons (July to September) and severe cold in winters, (December to February). Minimum temperature of the study area is usually recorded in the month of January and can be as low as $1.5 \pm 1.0^{\circ} \mathrm{C}$. However, maximum temperature may rise up to $45.5 \pm 1.5^{\circ} \mathrm{C}$ during the month of May/June. Annual average rainfall of the area usually ranges between $1300-1500 \mathrm{~mm}, 80 \%$ of which is received during the south-west monsoon during JulySeptember.

Remaining amount of rainfall is received during winter season (December to February) from "Western Disturbances". Maximum relative humidity ranges between $90-95 \%$ during monsoon as well as in winter season.

\section{Soil}

The soil of the experimental field is sandy loam, developed in loamy alluvial sediments. Soil was sandy loam in texture with $28.7 \%$ sand, $54.5 \%$ silt and $16.8 \%$ clay in the upper $15 \mathrm{~cm}$ layer of the soil with $1.3 \%$ organic carbon as determined after performing soil analysis.

\section{Weather data}

Weather data parameters for the years 201718including maximum and minimum temperatures, bright sunshine hours (BSS) and rainfall, were collected from the agrometeorological observatory located near the 
experimental site at Norman E. Borlaug Crop Research Centre, GBPUA\&T, Pantnagar.

\section{Experimental details}

The experiment was conducted during rabi 2017-18 using two factorial completely randomized design. The cultivar Pusa-362 was sown on three different dates viz. $29^{\text {th }}$ November, $10^{\text {th }}$ December and $24^{\text {th }}$ December, respectively. Two different irrigation levels were applied to the crop. In the $1^{\text {st }}$ level only one irrigation of $70 \mathrm{~mm}$ was applied while in the $2^{\text {nd }}$ level two irrigations of $70 \mathrm{~mm}$ each were applied (Table1).

\section{Number of root nodules per plant}

Number of root nodules per plant was recorded at 30, 45 and 60 DAS. To achieve the purpose, five randomly selected plants were uprooted from each plot. The roots were washed and the root nodules were counted.

\section{Dry weight of root nodules per plant}

Dry weights of root nodules per plant were recorded, at 30, 45 and 60 DAS. The plants uprooted for recording the number of root nodules were used to measure dry weight of root nodules per plant. The root nodules were isolated carefully from the plant roots and were kept in oven at $70^{\circ} \mathrm{C}$ for 24 hours and subsequently the dry weight of nodules were recorded.

\section{Results and Discussion}

\section{Number of root nodules per plant}

The data reveal significant differences among all the treatments. The maximum number of root nodules per plant was recorded at 60 DAS followed by 45 DAS and 30 DAS in all the treatments (Figure 1a). The sowing dates have significant effect on number of root nodules with $1^{\text {st }}$ date of sowing (29 November) producing highest number of nodules followed by $2^{\text {nd }}\left(10\right.$ December) and $3^{\text {rd }}$ ( 24 December) date of sowing, respectively. At 30 DAS, number of root nodules per plant for crop sown on 29 November remained at par with those sown on 10 December and 24 December, respectively. Sethi et al., (2015) also found at Hisar, Haryana that late sowings reduced number of root nodules in the chickpea crop.

The difference in number of root nodules per plant as produced by levels of irrigation were also found significant at all growth stages with two irrigations causing an increase in number of nodules per plants as compared to one irrigation as depicted in Figure $1 \mathrm{~b}$. The interaction between date of sowing and levels of irrigation was found to be non-significant. Parihar and Tripathi (1989) reported that increasing the amount and frequency of irrigation reduced the number and dry weight of nodules per plant.

Figures $2 \mathrm{a}$ and $2 \mathrm{~b}$ indicate that relative growth rate of number of root nodules per plant is negatively correlated with temperature $\left(\mathrm{R}^{2}=\right.$ $0.3628)$ and positively correlated with relative humidity $\left(\mathrm{R}^{2}=0.3365\right)$ on removal of two outliers. However, in the presence of outliers, the relationship with temperature $\left(\mathrm{R}^{2}=\right.$ $0.0531)$ and relative humidity $\left(\mathrm{R}^{2}=0.223\right)$ was relatively poor. The amount of nodulation in the first sown chickpea crop was higher than that of subsequent sowings. This led to the inference that with decreasing temperature, the amount of nodulation is decreasing. However, it will be important to mention that entire field was irrigated (pre-sowing irrigation for seed germination) once at the time of first sowing, while subsequent sowings were carried out in relatively dry soil conditions. Therefore, probability goes in favour of dry soil condition, which largely influenced establishment of nodulation than 
the temperature. Low initial soil moisture, especially for $2^{\text {nd }}(10$ December $)$ and $3^{\text {rd }}(24$ December) dates of sowing, has led to low initial settlement of number of root nodules per plant. The development, however, took place over initially formed number of root nodules. Thus, total number of root nodules per plant was higher in $1^{\text {st }}$ (29 November) date of sowing, but relative growth in successive dates of sowing were more than $1^{\text {st }}$ which confirms that low temperature is favorable for multiplication in number of root nodules.

\section{Dry weight of root nodules per plant (mg)}

Dry weight of root nodules per plant was recorded at 30, 45 and 60 DAS. The average dry weight of root nodules per plant is presented in Table 2. The data revealed that date of sowing produced significant difference at all the growth stages with considerable reduction in dry weight of root nodules induced by delay in date of sowing (Figure 3a).

Dry weight of root nodules in plants ranged from 9.83 to $17.83 \mathrm{mg}, 22.67$ to 40 , and 39.17 to $55 \mathrm{mg}$ for plants sown on 29 November, 10 December, and 24 December, respectively. The results agreed well with those obtained by Sethiet al., (2015).

The difference in dry weight of root nodules per plant as produced by irrigation levels was also found significant at 30 and 60 DAS but non-significant at 45 DAS. Two irrigations recorded higher dry weight of root nodules per plant at all growth stages as compared to one irrigation, however, the difference produced was not distinct enough (Figure 3b). Interaction effect of date of sowing and irrigation level appeared to be non-significant. In relation to weather variables, relative growth rate of dry weight of root nodules per plant has indicated a positive correlation with relative humidity $\left(\mathrm{R}^{2}=0.2129\right)$ and negative correlation $\left(\mathrm{R}^{2}=0.3185\right)$ with temperature on exclusion of two outliers (Figures $4 a$ and $4 b$ ).

However, in the presence of outliers the relative growth rate of dry weight of root nodules has shown a weak negative correlation with temperature $\left(\mathrm{R}^{2}=0.0125\right)$ and very weak positive correlation with relative humidity $\left(\mathrm{R}^{2}=0.0047\right)$. As in case of number of root nodules, soil moisture is supposed to be the reason behind overall lesser gain in dry weight of root nodules per plant in $2^{\text {nd }}(10$ December) and $3^{\text {rd }}$ (24 December) dates of sowing than $1^{\text {st }}$ sowing (29 November). The gain in dry weight of root nodules took place over initially formed nodule mass which was dependent on temperature and thus, relative growth in dry weight of nodule is more as the sowing date is delayed to cooler environment.

Highest values of dry weight $(55 \mathrm{mg})$ and number of root nodules (30.83) per plant were registered with $29^{\text {th }}$ November sowing and decreased as date of sowing was delayed to December. Two irrigations resulted into increased number and higher mass of nodulation as compared to one irrigation.

In relation to weather parameters, on exclusion of two outliers from the data, a satisfactory negative correlation $\left(\mathrm{R}^{2}=0.3628\right)$ was observed between RGR of number of root nodules per plant and temperature. The same has shown a positive correlation with relative humidity $\left(\mathrm{R}^{2}=0.3365\right)$. The relative gain in dry weight of root nodules per plant has also been found to be negatively correlated with mean temperature $\left(\mathrm{R}^{2}=0.3185\right)$ and positively correlated with relative humidity $\left(\mathrm{R}^{2}=\right.$ 0.2129). 
Table.1 Treatment details

\begin{tabular}{|c|c|}
\hline Treatment & Dates of sowing \\
\hline D1 & $29^{\text {th }}$ November \\
\hline D2 & $10^{\text {th }}$ December \\
\hline D3 & $24^{\text {th }}$ December \\
\hline Treatment & Levels of irrigation \\
\hline I1 & One irrigation \\
\hline I2 & Two irrigation \\
\hline
\end{tabular}

Table.2 Temporal variation in number of root nodules per plant in chickpea crop as influenced by different dates of sowing and irrigation levels

\begin{tabular}{|c|c|c|c|}
\hline \multirow{2}{*}{ Treatments } & \multicolumn{3}{|c|}{ Number of root nodules/ plant } \\
\cline { 2 - 4 } & 30DAS & 45 DAS & $\mathbf{6 0}$ \\
\hline & $\mathbf{A}$. & Date of sowing: \\
\hline 29 Nov & 14.33 & 24.17 & 30.83 \\
\hline 10 Dec & 8.33 & 19.83 & 25.83 \\
\hline 24 Dec & 8.17 & 16.33 & 24.67 \\
\hline SE(m) \pm & $\mathbf{1 . 1 9}$ & $\mathbf{1 . 2 1 7}$ & $\mathbf{1 . 1 4 7}$ \\
\hline CD $(\mathbf{p = 0 . 0 5})$ & $\mathbf{3 . 7 0 8}$ & $\mathbf{3 . 7 9 2}$ & $\mathbf{3 . 5 7 2}$ \\
\hline & $\mathbf{B .}$ & Levels of irrigation & \\
\hline One irrigation & 8.78 & 18.44 & 25.67 \\
\hline Two irrigations & 11.78 & 21.78 & 28.56 \\
\hline SE(m) \pm & $\mathbf{0 . 9 7 2}$ & $\mathbf{0 . 9 9 4}$ & $\mathbf{0 . 9 3 6}$ \\
\hline CD $(\mathbf{p}=\mathbf{0 . 0 5})$ & $\mathbf{3 . 0 2 8}$ & $\mathbf{3 . 0 9 6}$ & $\mathbf{2 . 9 1 7}$ \\
\hline
\end{tabular}

Table.3 Temporal variation in dry weight of root nodules (mg) per plant in chickpea crop as influenced by different dates of sowing and irrigation levels

\begin{tabular}{|c|c|c|c|}
\hline \multirow{2}{*}{ Treatments } & \multicolumn{3}{|c|}{ Dry weight of root nodules $(\mathrm{mg}) /$ plant } \\
\hline & 30DAS & 45 DAS & 60 DAS \\
\hline \multicolumn{4}{|c|}{ C. Date of sowing: } \\
\hline 29 Nov & 17.83 & 40.00 & 55.00 \\
\hline 10 Dec & 12.33 & 30.17 & 46.00 \\
\hline 24 Dec & 9.83 & 22.67 & 39.17 \\
\hline $\mathrm{SE}(\mathrm{m}) \pm$ & 0.714 & 1.319 & 1.371 \\
\hline $\mathrm{CD}(\mathrm{p}=\mathbf{0 . 0 5})$ & 2.223 & 4.11 & 4.271 \\
\hline \multicolumn{4}{|c|}{ D. Levels of irrigation } \\
\hline One irrigation & 12.33 & 30.67 & 44.56 \\
\hline Two irrigation & 14.33 & 31.22 & 48.89 \\
\hline $\mathrm{SE}(\mathrm{m}) \pm$ & 0.583 & 1.077 & 1.119 \\
\hline $\mathrm{CD}(\mathrm{p}=\mathbf{0 . 0 5})$ & 1.815 & NS & 3.487 \\
\hline
\end{tabular}


Fig.1 Temporal variation in number of root nodules per plant in chickpea crop as influenced by different (a) dates of sowing, (b) irrigation levels
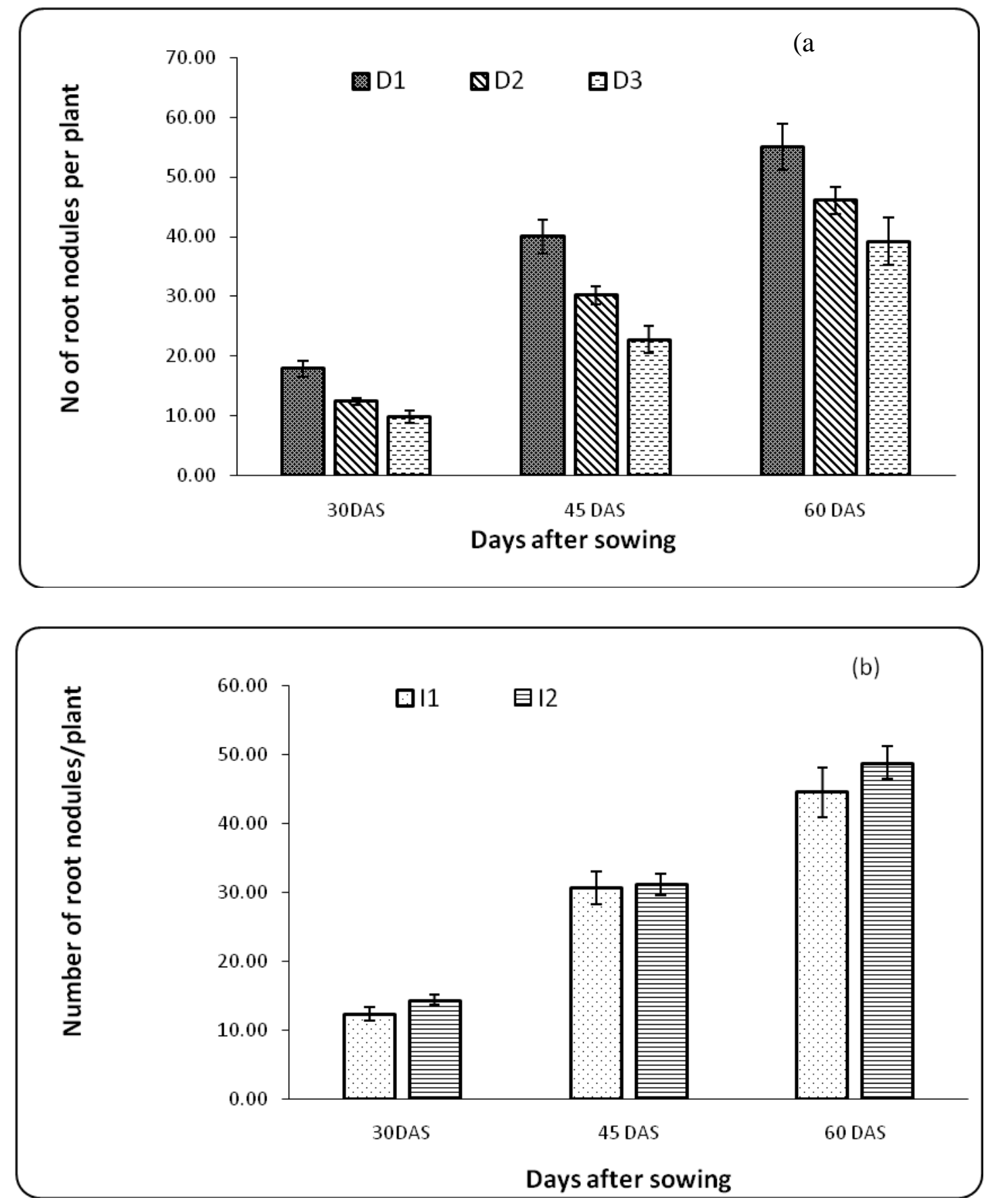
Fig. 2 Effect of (a) mean temperature $\left({ }^{\circ} \mathrm{C}\right)$, (b) relative humidity $(\%)$ on relative growth rate of number of root nodules per plant

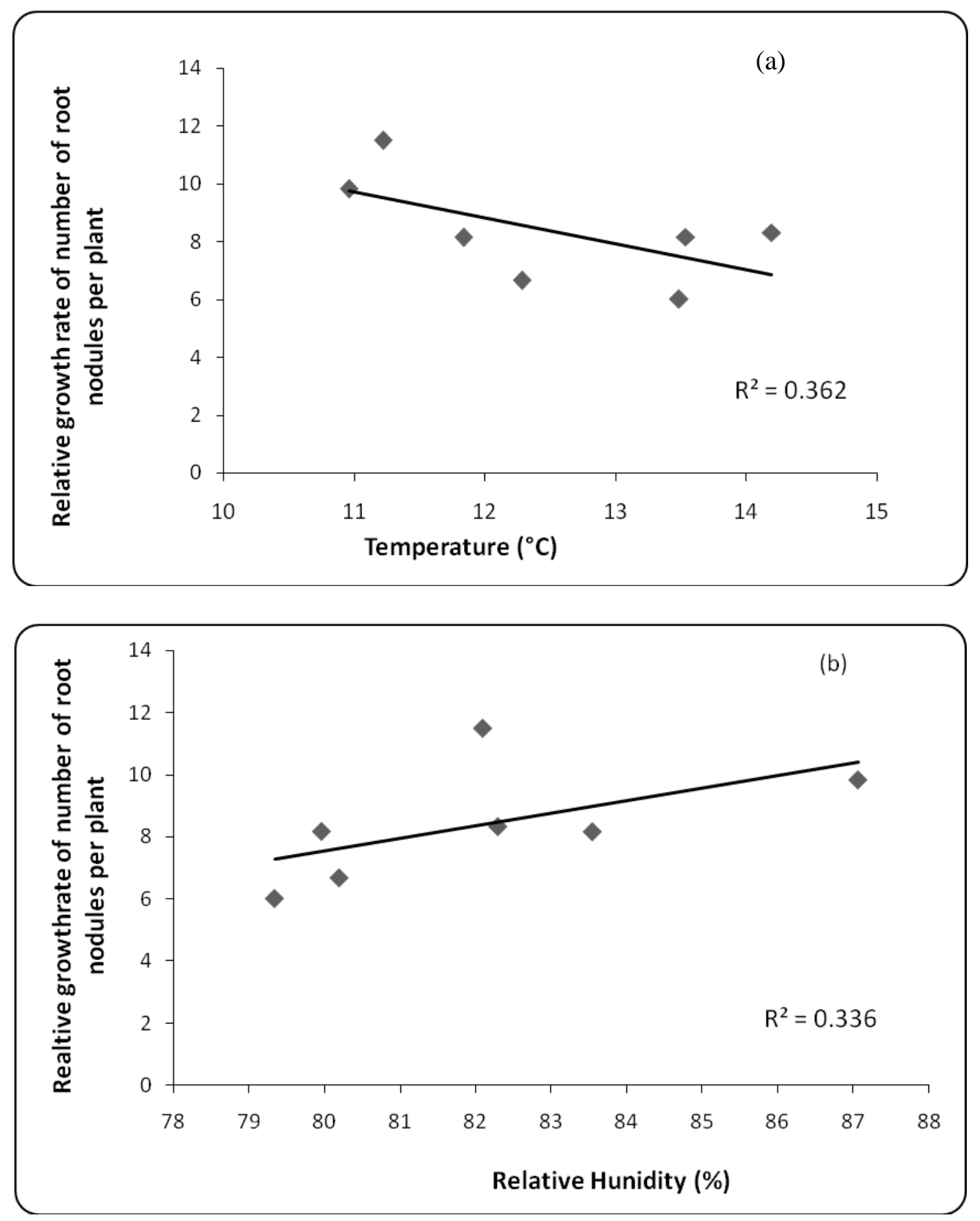


Fig.3 Temporal variation in dry weight of root nodules (mg) per plant in chickpea crop as influenced by different (a) dates of sowing, (b) irrigation levels

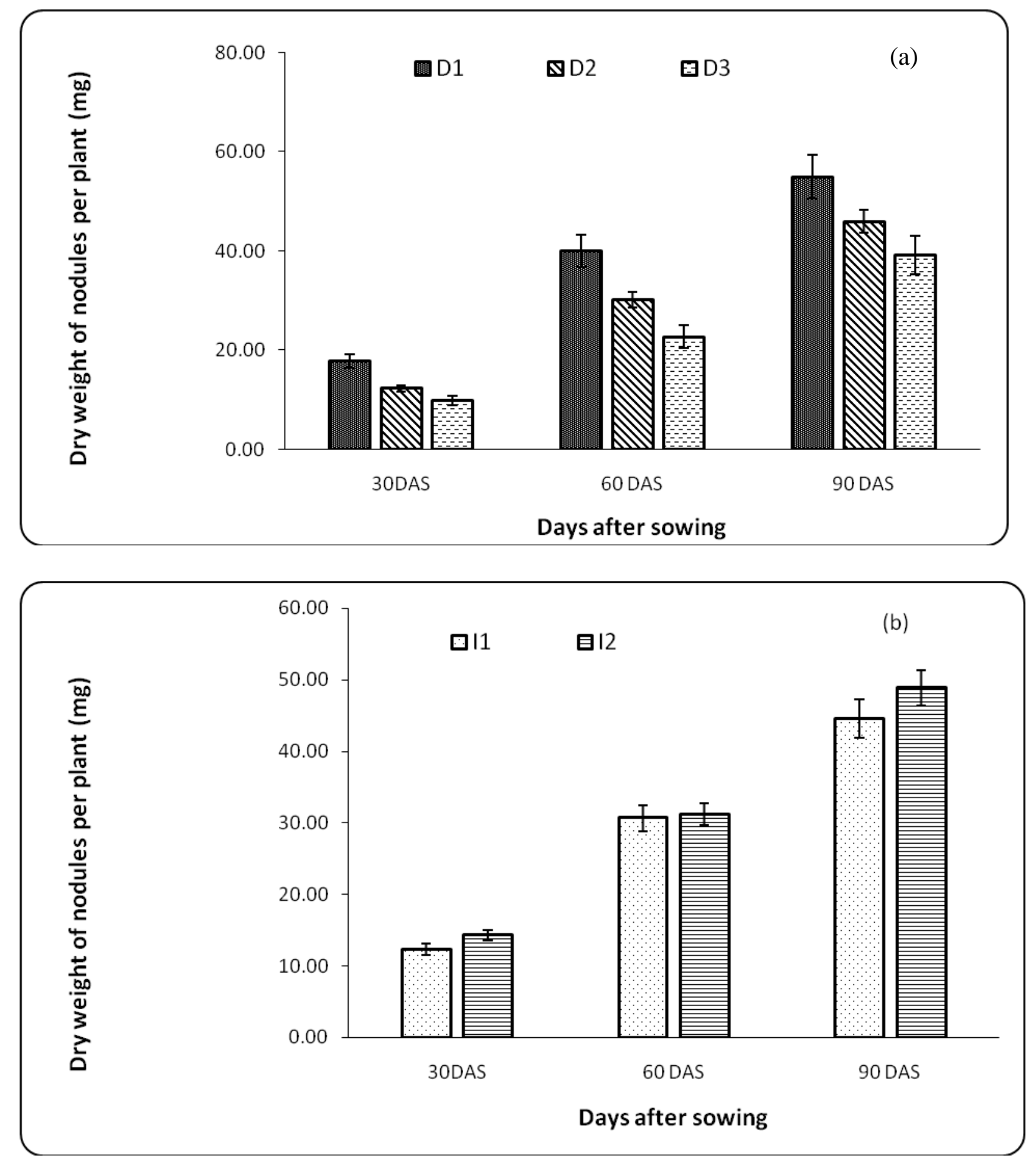


Fig.4 Effect of (a) mean temperature $\left({ }^{\circ} \mathrm{C}\right)$, (b) relative humidity $(\%)$ on relative growth rate of dry weight $(\mathrm{mg})$ of root nodules per plant
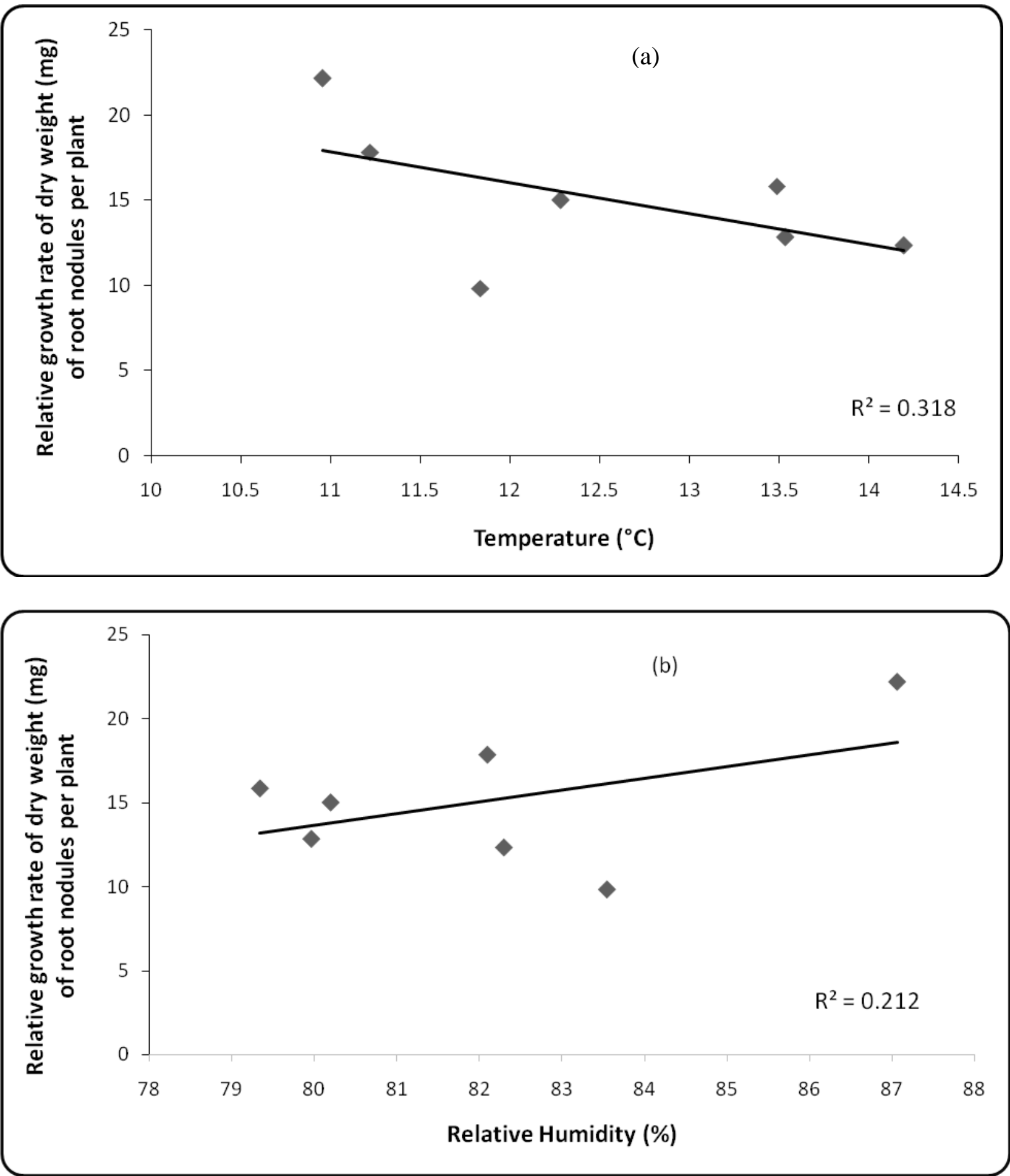
These findings on nodulation dynamics suggested that nodulation (number and dry weight) decreases with increasing temperature. Therefore, chickpea crop should not be sown very early when temperature is high. Soil moisture is another factor which used to influence growth of nodules. It has been noticed that good amount of moisture (not high) plays a catalytic role in sustaining high growth of nodules.

\section{References}

Bordeleau, L. M., and Prévost, D. 1994. Nodulation and nitrogen fixation in extreme environments. Plant and Soil, 161 (1): 115-125.

DAC\&FW. 2018. Pulses Revolution - From Food to Nutritional Security (2018): Min. of Agri. \& FW (DAC\&FW), GOI.
Lira M.D., Lima A.S.T., Arruda J.R.F., Smith D.L. 2005. Effect of root temperature on nodule development of bean, lentil and pea. Soil Biology and Biochemistry, 37: 235-239.

Parihar, S. S., and Tripathi, R. S. 1989. Dry matter, nodulation and nutrient uptake in chickpea (Cicer arietinum) as influenced by irrigation and phosphorus. Experimental agriculture, 25(3): 349-355.

Serraj, R., and Sinclair, T. R. 1998. Soybean cultivar variability for nodule formation and growth under drought. Plant and Soil, 202(1):159-166.

Sethi, I. B., Sewhag, M., Kumar, R., Kumar, P., and Jajoria, M. 2015. Studies on nodulation of chickpea cultivars as influenced by sowing time and seed rate. Ecology, Environment and Conservation, 22: 363-365.

\section{How to cite this article:}

Sonam Sah, R.N. Singh and Nain, A.S. 2019. Impact of Different Dates of Sowing and Irrigation Levels on Chickpea Nodulation. Int.J.Curr.Microbiol.App.Sci. 8(11): 705-714. doi: https://doi.org/10.20546/ijcmas.2019.811.085 